\title{
ASSESSMENT OF AN IMPACT OF MECHANICAL REGULATION ON SELECTED MORPHOMETRIC AND PRODUCTIVE PARAMETERS OF INVASIVE SPECIES SOLIDAGO CANADENSIS POPULATION IN AGRICULTURAL LAND
}

\author{
LÝDIA KONČEKOVÁ*, EVA ZAHRADNÍKOVÁ, EDUARD PINTÉR, DANIELA HALMOVÁ
}

Slovak University of Agriculture in Nitra, Slovak Republic

KONČEKOVÁ, L. - ZAHRADNíKOVÁ, E. - PINTÉR, E. - HALMOVÁ, D.: Assessment of an impact of mechanical regulation on selected morphometric and productive parameters of invasive Solidago canadensis population in agricultural land. Agriculture (Pol'nohospodárstvo), vol. 61, 2015, no. 4, pp. 121-128.

Repeated mowing is considered as one of the effective control methods against species of the genus Solidago. This paper evaluates the impact of the repeated mowing on selected morphometric and productive characteristics of the invasive neophyte Solidago canadensis in the district of Rimavská Sobota in Central Slovakia. Permanent research plots (PRPs) were established within anthropogenic habitat on an abandoned land that was divided into two variants. In the first variant, the mechanical regulation - mowing was applied. The second variant was without the regulation. The mechanical regulation of the populations was carried out in June and August during the growing season 2011. The results showed that the mechanical regulation did not have a clear impact on the population density. The decreasing trend of the number of shoots within the mowed variant was found only in one research plot (PRP3). The other plots showed an increase in the number of individuals by 2.7 and $32.7 \%$ between the mowings. Statistically highly significant differences in terms of the mowing impact on the height of the individuals were found in all PRPs. The difference in the weight of dry aboveground biomass between the mowings was $221.87 \mathrm{~g}$, which represents $36.41 \%$. Double the difference $(48.8 \%)$ was recorded in the dry weight of the underground biomass in the regulated stand compared with the unregulated stand (165.1 and $322.5 \mathrm{~g} / \mathrm{m}^{2}$, respectively). Although there was a short-term success achieved by the application of the two mowings during the growing period, the pursued objective was not reached.

Key words: agricultural land, alien plant, mowing, regulation, Solidago canadensis

In Europe, changes in the traditional way of land management lead to the land degradation and changes in diversity and structure of ecosystems (Stoate et al. 2009; Navarro \& Pereira 2012; Fehér et al. 2012). Abandonment of formerly managed lands is a result of changes in local and global economy as well as changes of social and political conditions and depopulation of rural areas (Cramer et al. 2008; Midriak et al. 2011). These changes often lead to an increasing number of large unproductive areas, mostly abandoned fields. Farmland abandonment may both negatively and positively affect biodiversity (Queiroz et al. 2014). A negative consequence of such a change of land use is an expansion of aggressive weed species and/or these areas become more susceptible to invasion by alien species. Several authors (Lambdon et al. 2008; Chytrý et al. 2009; Szymura \& Szymura 2013) indicate that mainly abandoned fields are prone to establishment of invasive species of the genus Solidago in Europe.

Ing. Lýdia Končeková, PhD. (*Corresponding author), Department of Ecology, Faculty of European Studies and Regional Development, Slovak University of Agriculture in Nitra, Mariánska 10, 94976 Nitra, Slovak Republic. E-mail: lydia. koncekova@uniag.sk

Ing. Eva Zahradníková, Faculty of European Studies and Regional Development, Slovak University of Agriculture in Nitra, Mariánska 10, 94976 Nitra, Slovak Republic

Ing. Eduard Pintér, PhD., Faculty of Horticulture and Landscape Engineering, Slovak University of Agriculture in Nitra, Tulipánova 7, 949 76, Nitra, Slovak Republic

Ing. Daniela Halmová, PhD., Faculty of European Studies and Regional Development, Slovak University of Agriculture in Nitra, Mariánska 10, 94976 Nitra, Slovak Republic 
Therefore, it is necessary to ensure radical management treatments resulting from the knowledge of these species (Hobbs \& Humphries 1995; Child \& Wade 2000; Wittenberg \& Cock 2001; Myers \& Bazely 2003; EEA 2010). Some authors suggest several methods of the invasive species control including mechanical, chemical and biological regulation (D’Antonio \& Meyerson 2002; Musil et al. 2005). Mechanical control (e.g. mowing, cutting, uprooting) is preferred in cases when the population of invasive species occupy a small area, or a few individuals occur (Zárubová-Prausová 2001). A disadvantage of this control is that intensive manual work always prevails and regulation must be repeated for several years to remove all individuals (Wittenberg \& Cock 2001).

Solidago canadensis L. (Canadian goldenrod) is a perennial weed, native of North America (including eastern and southern USA, Canada and Mexico) (Wagenitz 1979) that is among the most successful invasive plant species in the world (Weber 2003). This exotic herbaceous plant (family Asteraceae) is characterised by erect and unbranched stem, up to $2 \mathrm{~m}$ high with creeping rhizomes. Alternate stalkless leaves are lanceolate with serrulate margins. The species flowers from August to October. Fruit is pubescent achenes (Dostál \& Červenka 1992). In the wild, it settles mainly at synanthropical sites as well as abandoned farmland, accompanying vegetation of streams, river banks and infrequently grazed pastures (Werner et al. 1980; Voser-Huber 1992). Its invasive potential is achieved by effective combination of vegetative growth (that enables the plant to occupy habitats in short distance) and long-distance dissemination (that helps to penetrate to new locations). The species prefers open, sunny, little shaded habitats with sandy soil. However, it tolerates a fairly wide range of soil fertility and texture conditions (Werner et al. 1980). In Slovakia, its optimum conditions of distribution can be found in upland level, but it also occurs in lowlands and foothill areas. Medvecká et al. (2012) reported that the species was introduced into Slovakia in 1872. Lohmeyer and Sukopp (1992) include the species into agriophytes of Central Europe. Communities with S. canadensis are floristically moderately rich and are classified within the class Galio-Urticetea Passarge ex Kopecký (1969), order Convolvuletalia sepium R.
Tx. (1950), alliance Senecionion fluviatilis R. Tx. (1950) or alliance Aegopodion podagrariae TX. 1967 (Jarolímek et al. 1997; Jarolímek \& Zaliberová 2001). S. canadensis also occurs in xerophilous ruderal vegetation class Artemisietea vulgaris Lohmeyer et al. in R. Tx. ex von Rochow (1951), order Onopordetalia acanthii Br.-Bl. et R. Tx. ex Klika et Hadač (1944), alliance Dauco-Melilotion Görs (1966) or alliance Arction lappae R. Tx. (1937) (Láníková et al. 2009). Several characteristics (fast escaped into wild, creating homogeneous dense vegetation and spreading by the long rhizomes, high production and good seed germination, various options of spreading and production of allelopathic substances) contribute to the mass spread of the species. In accordance with the Act no. 543/2002 Coll. on Nature and Landscape Protection and Decree of the Ministry of the Environment No. 158/2014, S. canadensis is included among invasive plant species that must be removed from the environment. In Slovakia, it easily occupies disturbed anthropogenic sites, but in recent years, it can also be found in the closed stands of grasses and begins to penetrate into abandoned agricultural land. Thanks to its ecological plasticity, the species begins to occur casually also on arable land (Mižík 2006). The aim of this paper is to assess an impact of the mechanical regulation (mowing) that is considered an effective control method on selected morphometric and production indicators/parameters of the invasive species $S$. canadensis stands.

\section{MATERIAL AND METHODS}

PRPs were established in the cadastral area of Potok village (Rimavská Sobota district) with a total area of 513 ha. The area is situated in the southeast region of Slovak Ore Mountains in Revúca highland, in the valley of the stream Blh that belongs to the water catchment area of river Slaná. The altitude of the village is $310 \mathrm{~m}$ above sea level (a.s.l.), varying from 300 to $508 \mathrm{~m}$ a.s.l. in the whole cadastral area. Its nature classifies it to hill land and highland areas. The area belongs to warm climate region and warm, moderately wet zone with cold winter (Lapin et al. 2002). Prevailing soils are cambisols modal and anthrosol with low to medium humus content 
(Bielek 2002; Šály \& Šurina 2002). The production potential of the agricultural land as well as the index of the agricultural potential is low (Džatko et al. 2002). S. canadensis was recorded in different types of habitats in the studied area: riparian vegetation, fragments of moist to wet meadows, built-up area of the village and pastures (Kliment et al. 2000).

The experiment was established within anthropogenic habitat on an abandoned land that was formerly used for growing various agricultural crops. The dominant species was $S$. canadensis $\mathrm{L}$. covering 80\%. The accompanying species involved Arctium lappa L., Armoracia rusticana P. Gaertn., B. Mey. et Scherb., Cirsium arvense (L.) Scop., Lamium purpureum L., Leucanthemum vulgare Lam., Stellaria media (L.) Vill., Taraxacum sect. Ruderalia Kirschner, H. Øllg. et Štěpánek and Urtica dioica L. The total size of this abandoned field was $12.4 \times 25.6 \mathrm{~m}$. The area was divided into two partial sections. One section represented a variant where the mechanical regulation - mowing was applied. This variant included three PRPs (PRPs 1-3) with an area of $1 \times 1 \mathrm{~m}$. The plots were set out further from the stand edges to avoid negative impact of the edge effect. Mechanical regulation of the populations was carried out by repeated mowing on June $8^{\text {th }} 2011$ and August $30^{\text {th }}$ 2011. Only the aboveground parts of the plants were removed by the mowing. The dates of measurements and sampling of the plant material for its further assessment corresponded with the dates of the mowing. The whole aboveground biomass was removed from the rest of the area to avoid growth support by underground organs. The second part of the plot represented a variant without the use of regulatory measures - mowing. Similarly, to the first part, three PRPs (PRPs 4-6) with an area of $1 \times 1 \mathrm{~m}$ were established. The dates of measurements corresponded with the dates of the mowing. The population density (stem/ramet per $\mathrm{m}^{2}$ ) was determined by the census of ramets in both variants. The plant height was determined by measuring the length of the main stem (from the base to the apex). The sampling of the total aboveground biomass was performed in the variant with the application of the mechanical regulation twice during the growing season 2011. All individuals growing in the PRPs were collected. Fresh weights of the biomass as well as dry weights after the drying of the samples in the labora- tory at $85^{\circ} \mathrm{C}$ were investigated. The sampling of the underground biomass was conducted at the end of the growing season - October $29^{\text {th }} 2011$. The underground biomass was collected from an area of $1 \mathrm{~m}^{2}$ in both variants. The significance of differences (at $P<0.05$ ) in plant height between both mowings was checked by the statistical method (Analysis of variance - ANOVA) using the Tukey test.

\section{RESULTS AND DISCUSSION}

The results of the evaluation of the population densities between the first and the second mowing showed that the number of individuals increased in the plots PRP 1 by $2.7 \%$ and PRP 2 by $32.7 \%$. Unlike the first two variants, a declining trend in the number of individuals between the mowings was recorded in the plot PRP3 (by 7.98\%). It can be concluded that mechanical regulation did not have a clear impact on the number of individuals. Several authors (cf. Joshi \& Matthies 1996; Rebele \& Lehmann 2002; Cvachová \& Gojdičová 2003) reported that the most effective result can be achieved by repeated mowing at least twice a year in the vegetative phase, that is, before the formation of inflorescences in late July and early August and/or in May and August. This leads to a reduction of soil seed stocks and their further spread to new locations. The regular mowing weakens plants and encourages other vegetation at the expense of the goldenrod. There were no changes in the number of individuals between the measurements recorded in PRPs without application of the mechanical regulation compared with the variants where the mowing was provided. The number of individuals observed in early June corresponded to the number of individuals observed in late August in the individual PRPs (PRP4 - 117, PRP5 - 134 and PRP6 - 131 individuals per $\mathrm{m}^{2}$ ). In Switzerland, Joshi and Matthies (1996) recorded lower coverage of $S$. canadensis after 5 years of annual mowing in a mowed variant $(12 \%)$ compared with a variant that was not mowed (41\%).

The key factor for a better adaptation of alien species into environmental conditions and competition with native species in non-native region is a phenotypic plasticity (e.g. shoot height and biomass allocation to shoot and root). The evaluation of the 
population size structure in the regulated variant revealed that the studied populations were formed mostly by individuals belonging to the fifth (78.1$93 \mathrm{~cm})$ and sixth $(93.1-108 \mathrm{~cm})$ size class at the first mowing of all three PRPs. These individuals accounted for $75 \%$ on PRP1, $75.46 \%$ on PRP2 and $65.03 \%$ on PRP3 (Figure 1).

Huang et al. (2007) reported that the vegetative growth period was mainly from March to September and summer was an overgrowth period for vegetative growth and clonal reproduction in the subtropical conditions of China's eastern coastal area. In Central Slovakia, the height increments regularly achieved maximum value at the end of July during the period 2000-2002 (Mooschová 2006).

At the second mowing, the highest proportion of individuals was in the third $(48.1-63 \mathrm{~cm})$ and the fourth $(63.1-78 \mathrm{~cm})$ size class in all three PRPs (Figure 2). These individuals represented $47.37 \%$ of all individuals on PRP1, 59.59\% on PRP2 and $46.66 \%$ on PRP3. The third size class was the most abundant in all PRPs. The analysis of variance revealed statistically highly significant differences in terms of impact of the mowing on height of individuals in all PRPs (Table 1).

At the second mowing provided in late August, the height parameters were lower compared with the first mowing provided in early June and plants did not create inflorescences. Our results correspond with finding of Cvachová and Gojdičová (2003), who recorded that the lower vitality and lower growth of individuals is contributed to the mechanical destruction of invasive species. The plant height and the size of the inflorescences affect the invasive potential of the species (cf. Melville \& Morton 1982). Effective control of the creation and dissemination of seeds is essential in order to prevent spread of the invasive species over great distances (Wittenberg \& Cock 2001; Wilson et al. 2009; Guo et al. 2009).

Some authors (Yuan 2008; Domaradzki \& Badowski 2012) recommended a chemical regulation of Solidago species in non-arable and fallow land using herbicides containing selected active ingredients. Chemical control represents an effective method to control the growth of underground rhizomes of S. canadensis (Yuan 2008).

The dry weight of the aboveground biomass in the regulated variant achieved the highest value at the first mowing in all three PRPs. The individuals had the highest and the thickest stems and the largest number of leaves and internodes in that period. The average weight of the dry aboveground biomass was $609.33 \mathrm{~g} / \mathrm{m}^{2}$ at the first mowing and $387.46 \mathrm{~g} / \mathrm{m}^{2}$ at the sec-

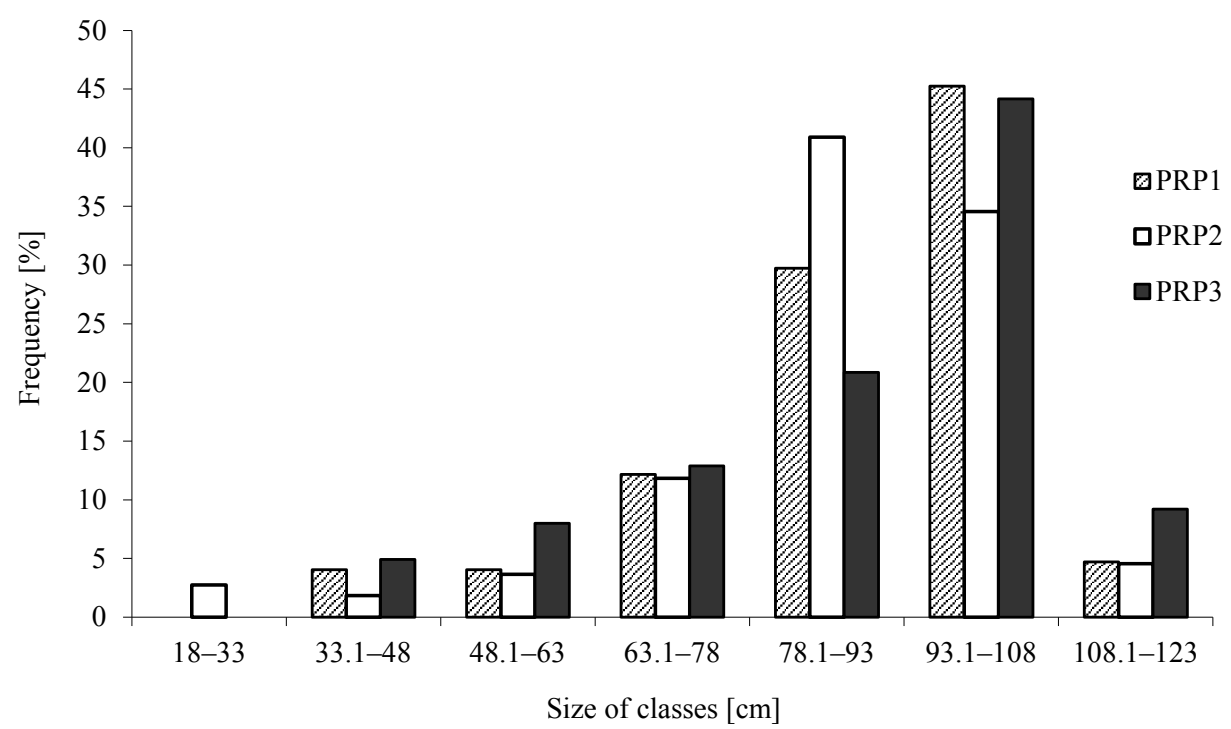

Figure 1. Size structure of height of Solidago canadensis at the first mowing on permanent research plot 1 (PRP1), permanent research plot 2 (PRP2) and permanent research plot 3 (PRP3) in June 2011 
ond mowing (the difference between mowings was $221.87 \mathrm{~g} / \mathrm{m}^{2}-$ Figure 3 ).

Biomass allocation to individual functionally important parts of plants (e.g. underground rhizomes, roots) leads to increased access to resources that can support individual clonal shoots in a later period. The evaluation of the dry and fresh weight of the underground biomass was made at the end of the growing period in both variants. A significant difference, almost double the difference, was recorded between the regulated and non-regulated variant (Figure 4).
The dry weight of the underground biomass was $165.1 \mathrm{~g}$ in the regulated variant and $322.5 \mathrm{~g}$ in the non-regulated variant.

\section{CONCLUSIONS}

The objective of this paper is to assess the application of one type of mechanical regulation - mowing provided two times per year that could be used for the control of $S$. canadensis stands in abandoned

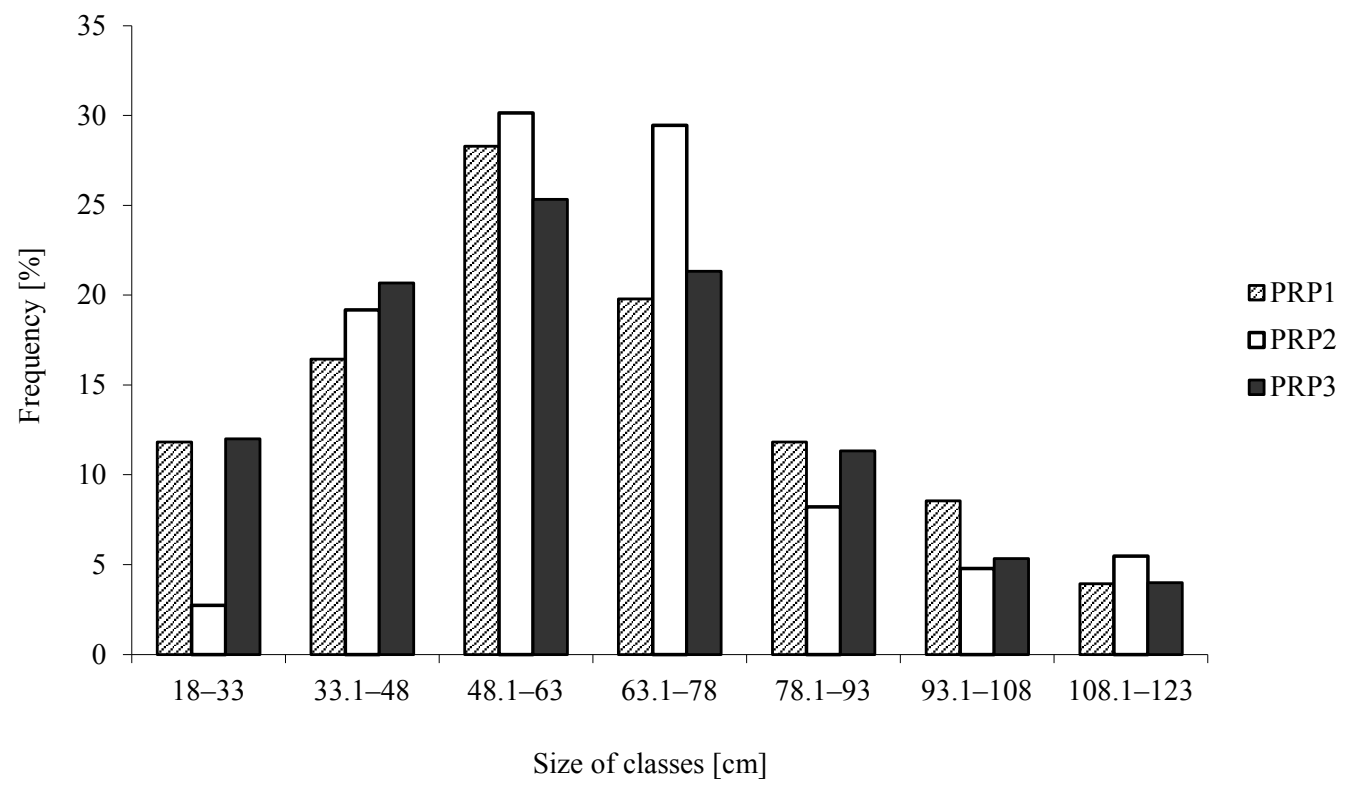

Figure 2. Size structure of height of Solidago canadensis at the second mowing in August 2011 Abbreviations see Figure 1

$\mathrm{T}$ a

Statistical evaluation of the impact of mowing on the height of Solidago canadensis individuals on PRPs

\begin{tabular}{|c|c|c|c|}
\hline Permanent research plot & $\begin{array}{c}\text { Differences in height } \\
\text { of shoots }\end{array}$ & Mowing & Homogeneous group [cm] \\
\hline PRP1 & ++ & 1 & $89.20^{\mathrm{a}}$ \\
\hline PRP2 & ++ & 2 & $62.57^{\mathrm{b}}$ \\
\hline PRP3 & ++ & 2 & $86.65^{\mathrm{a}}$ \\
& & 1 & $64.75^{\mathrm{b}}$ \\
\hline
\end{tabular}

Values followed by the different letters column-wise $(a, b)$ were significantly different in the Tukey test $(P<0.05) ;++$ statistically highly significant difference between the mowings

Abbreviations see Figure 1 
fields. The results show that it did not have a clear effect on reducing the number of individuals. Statistically highly significant differences in terms of the mowing impact on the height of the individuals were found in all PRPs and the average plant height was lower compared with the first measurement by 25.4 $\mathrm{cm}$. The dry weight of the aboveground biomass in the regulated variant was the highest at the first mowing in all PRPs when the individuals had the highest and thickest stems as well as the largest number of leaves and internodes in that period. The difference in the average values of the dry aboveground biomass between the mowings was $221.87 \mathrm{~g}$. The total dry weight of the aboveground biomass reached

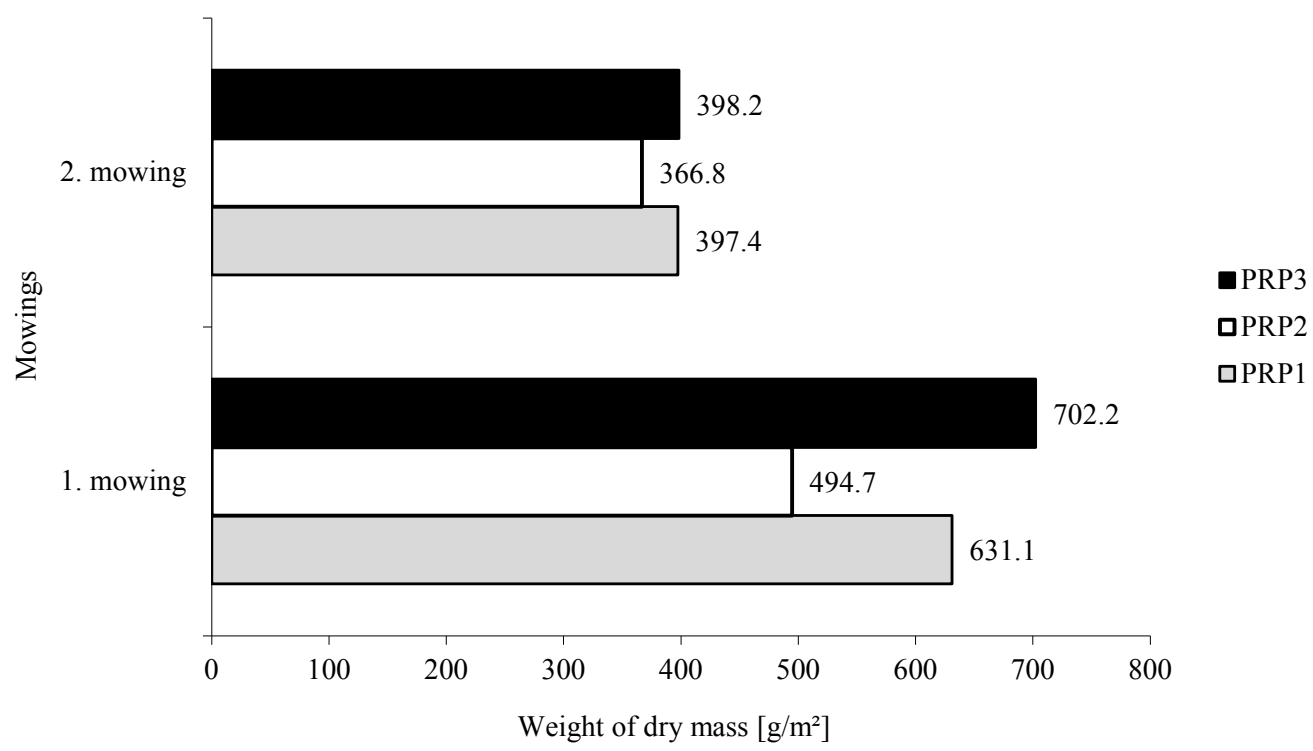

Figure 3. Weight of the dry aboveground biomass during the growing period 2011 Abbreviations see Figure 1

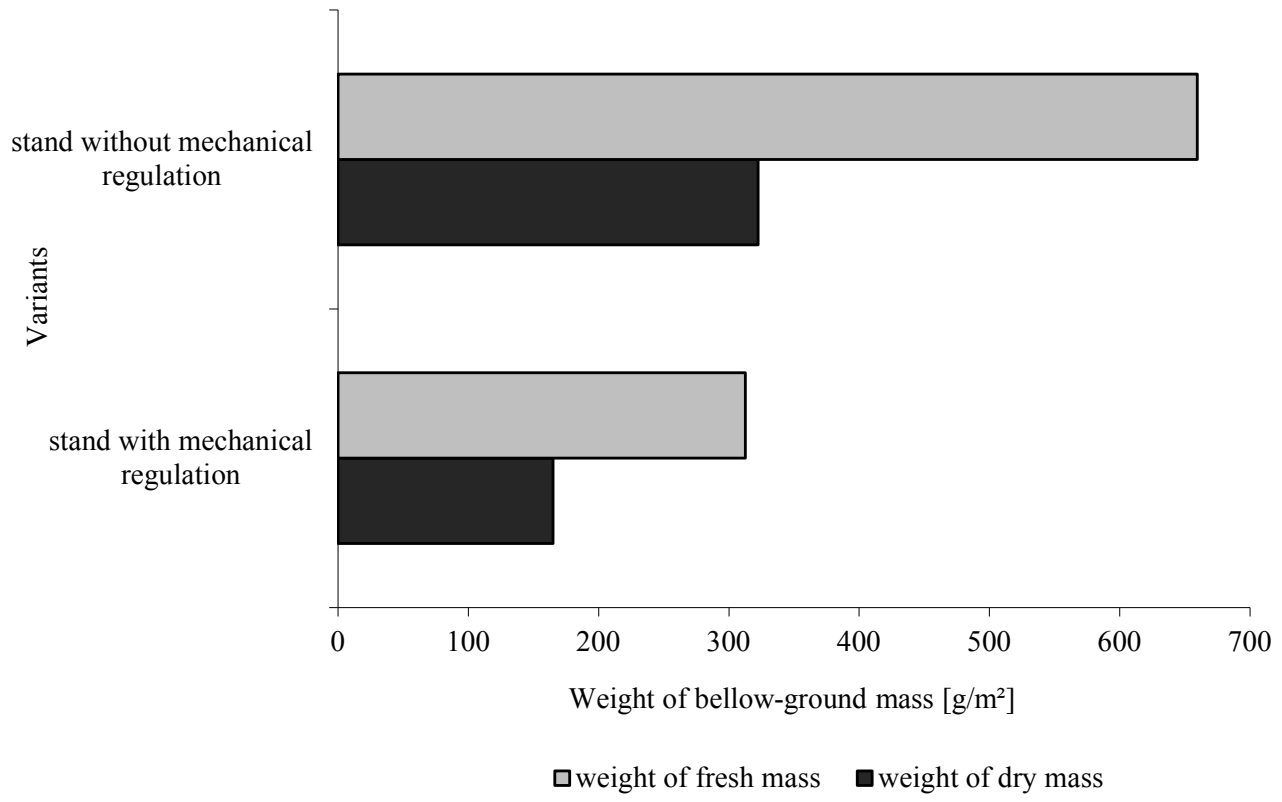

Figure 4. Weight of dry and fresh underground biomass in both regulated and unregulated stands in 2011 
about $1 \mathrm{~kg} / \mathrm{m}^{2}$ after the two mowings. The difference in the average weight of the fresh aboveground biomass between the mowings was $1201.66 \mathrm{~g}$. The total weight of the fresh aboveground biomass reached on average $5.3 \mathrm{~kg} / \mathrm{m}^{2}$ after the two mowings. A significant difference, almost double, was recorded in the dry and fresh weight of the underground biomass between the yields of the underground biomass in the regulated and non-regulated stand. Although there was a short-term success (decrease in the production of the aboveground and underground biomass and statistically highly significant effect on the height of individuals) achieved by the application of the two mowings during the growing period, the pursued objective was not reached. It is therefore proposed to supplement the mechanical regulation by a chemical regulation that would reduce the seed production and limit their germination and suppress the growth of underground rhizomes, thus preventing further spread of the species to new habitats.

Acknowledgements. This study was supported by the Slovak Grant Agency for Sciences (VEGA), grant Nr. 2/0117/13 Assessment of status and dynamics of habitats using combination of modelling and remote sensing.

\section{REFERENCES}

BIELEK, P. 2002. Obsah humusu v pol'nohospodárskych pôdach [Humus content in agricultural soils]. In Atlas krajiny Slovenskej republiky. Banská Bystrica : SAŽP, 342 pp. ISBN 80-88833-27-2.

CHILD, L. - WADE, M. 2000. The Japanese knotweed manual: the management and control of an invasive alien weed. Chichester : Packard Publishing Ltd, pp xi + 123 pp. ISBN 1853411272.

CHYTRÝ, M. - PYŠEK, P. - WILD, J. - PINO, J. MASKELL, L.C. - VILÀ, M. 2009. European map of alien plant invasions based on the quantitative assessment across habitats. In Diversity and Distribution, vol. 15, pp. 98-107. DOI: 10.1111/j.14724642.2008.00515.x.

CRAMER, V.A - HOBBS, R.J. - STANDISH, R.J. 2008. What's new about old fields? Land abandonment and ecosystem assembly. In Australia Trends in Ecology and Evolution, vol. 23, pp.104-112.

CVACHOVÁ, A. - GOJDIČOVÁ, E. 2003. Usmernenie na odstraňovanie inváznych druhov rastlín [Guidelines for removal of plant invasive species]. Banská Bystrica : ŠOP SR, 65 pp. ISBN 80-89035-25-6.

D'ANTONIO, C. - MEYERSON, L.A. 2002. Exotic plant species as problems and solutions in ecological restoration: a synthesis. In Restoration Ecology, vol. 10, pp. 703-713. DOI: 10.1046/j.1526-100X.2002.01051.x.

DOMARADZKI, K. - BADOWSKI, M. 2012. Possibility of chemical reduction of Solidago gigantea Aiton occurrence on fallow lands. In Zeszyty Naukowe Uniwersytetu Przyrodniczego we Wroclawiu - Rolnictwo, vol. 100, pp. 17-23.

DOSTÁL, J. - ČERVENKA, M. 1992. Vel'ký klúč na určovanie vyššich rastlín II. [Comprehensive key for the determination of vascular plants of Slovakia II.] Bratislava: SPN, 1565 pp. ISBN 80-08-00003-1.

DŽATKO, M. et al. 2002. Produkčný potenciál pol’nohospodárskych pôd [Productivity potential of agricultural soils]. In Atlas krajiny Slovenskej republiky. Banská Bystrica : SAŽP, 342 pp. ISBN 80-88833-272.

EEA, 2010. EU 2010 biodiversity baseline. Technical report. Copenhagen : EEA, 211 pp. ISSN 1725-2237.

FEHÉR, A. - KONČEKOVÁ, L. - GLEMNITZ, M. BERGER, G. - PFEFFER, H. - HERZON, I. 2012. Maintaining and promoting biodiversity. In JAKOBSON, CH. (Ed). Sustainable Agriculture. Uppsala : Baltic University Press, pp. 371-387. ISBN 978-9186189-10-5.

GUO, S.L. - JIANG, H.W. - FANG, F. - CHEN, G.Q. 2009. Influences of herbicides, uprooting and use as cut flowers on sexual reproduction of Solidago canadensis. In Weed Research, vol. 49, pp. 91-299. DOI: $10.1111 / \mathrm{j} .1365-3180.2009 .00693 . x$.

HOBBS, R.J. - HUMPHRIES, S.E. 1995. An integrated approach to the ecology and management of plant invasions. In Conservation Biology, vol. 9, pp. 761-770. DOI: 10.1046/j.1523-1739.1995.09040761.x.

HUANG, H. - GUO, S. - CHEN, G. 2007. Reproductive biology in an invasive plant Solidago canadensis. In Frontiers in Biology, vol. 2, pp. 196-204. DOI: 10.1007/s11515-007-0030-6.x.

JAROLÍMEK, I. - ZALIBEROVÁ, M. - MUCINA, L. - MOCHNACKÝ, S. 1997. Rastlinné spoločenstvá Slovenska. 2. Synantropná vegetácia [Plant communities of Slovakia. 2. Synanthropic vegetation]. Bratislava: Veda, pp. 420. ISBN80-224-0522-1.

JAROLÍMEK, I. - ZALIBEROVÁ, M. 2001. Convolvuletalia sepium. In VALACHOVIČ, M. (Ed). Rastlinné spoločenstvá Slovenska. 3. Vegetácia mokradi [Plant communities of Slovakia. 3. Vegetation of wetlands]. Bratislava: Veda, pp. 21-50. ISBN 978-80-224-06880 .

JOSHI, J. - MATTHIES, D. 1996. Effects of mowing and fertilization on succession in an old-field plant community. In Bulletin of the Geobotanical Institute ETH, no. 62, pp.13-26.

KLIMENT, J. - HRIVNÁK, R. - JAROLÍMEK, I. - VALACHOVIČ, M. 2000. Cievnaté rastliny Drienčanského krasu [Vascular plants of Drienčanský karst]. In Príroda Drienčanského krasu. Banská Bystrica : ŠOP SR, pp. 97-150. ISBN 80-968442-8-8.

LAMBDON, P.W. - PYŠEK, P. - BASNOU, C. - HEJDA, M. - ARIANOUTSOU, M. - ESSL, F. et al. 2008. Alien flora of Europe: species diversity, temporal 
trends, geographical patterns and research needs. In Preslia, vol. 80, pp. 101-149.

LÁNÍKOVÁ, D. - CHYTRÝ, M. - LOSOSOVÁ, Z. 2009. Suchomilná ruderální vegetace s dvoletými a vytrvalými druhy [Xerophilous ruderal vegetation with biennial and perennial species]. In CHYTRÝ, M. (Ed). Vegetace České republiky. 2, Ruderální, plevelová, skalní a sutová vegetace [Vegetation of the Czech Republic. 2, Ruderal, weed, rock and scree vegetation]. Praha : Academia, pp. 206-286. ISBN 97880-200-1769-7.

LAPIN, M. - FAŠKO, P. - MELO, M. - ŠŤASTNÝ, P. TOMLAIN, J. 2002. Klimatické oblasti [Climatic regions]. In Atlas krajiny Slovenskej republiky. Banská Bystrica : SAŽP, 342 pp. ISBN 80-88833-27-2.

LOHMEYER, W. - SUKOPP, H. 1992. Agriophyten in der Vegetation Mitteleuropas. Schriftenreihe für Vegetationskunde [Agriophytes in the vegetation of Central Europe. Series for vegetation science] Heft 25. Bundesforschungsanstalt für Naturschutz und Landschaftsökologie, Bonn-Bad Godesberg.

MEDVECKÁ, J. - KLIMENT, J. - MÁJEKOVÁ, J. HALADA, L. - ZALIBEROVÁ, M. - GOJDIČOVÁ, E. - FERÁKOVÁ, V. - JAROLÍMEK, I. 2012. Inventory of the alien flora of Slovakia. In Preslia, vol. 84, pp. 257-309.

MELVILLE, M.R. - MORTON, J.K. 1982. A biosystematic study of the Solidago canadensis (Compositae) complex. I. The Ontario populations. In Canadian Journal of Botany, vol. 60, pp. 976-997.

MIDRIAK, R. - ZAUŠKOVÁ, L. - SABO, P. - GALLAY, I. - GALLAYOVÁ, Z. - LEPEŠKA, T. 2011. Spustnuté pôdy a pustnutie krajiny Slovenska [Waste lands and abandoning of landscape in Slovakia]. Banská Bystrica : Fakulta prírodných vied, Univerzita Mateja Bela v Banskej Bystrici, pp. 401. ISBN 978-80-5570110-3

MIŽÍK, P. 2006. Zlatobyl' kanadská (Solidago canadensis) [Canadian goldenrod (Solidago canadensis)]. In Naše pole, vol. 10, pp. 26-27.

MOOSCHOVÁ, J. 2006. Hodnotenie invázneho potenciálu introdukovaných druhov rastlín: dizertačná práca [Evaluation of invasion potential of introduced plant species]. Nitra : SPU, $182 \mathrm{pp}$.

MUSiL, C.F. - MILTON, S.J. - DAVIS, G.W. 2005. The threat of alien invasive grasses to lowland Cape floral diversity: an empirical appraisal of the effectiveness of practical control strategies. In South African Journal of Science, vol. 101, pp. 337-344.

MYERS, J.H. - BAZELY, D.R. 2003. Ecology and control of introduced plants. Cambridge : Cambridge University Press, 2003, 313 pp. ISBN 0-521-35778-0.

NAVARRO, L.M. - PEREIRA, H.M. 2012. Rewilding abandoned landscapes in Europe. In Ecosystems, vol. 15, pp. 900-912. DOI:10.1007/s10021-0129558-7.

QUEIROZ, C. - BEILIN, R. - FOLKE, C. - LINDBORG, R. 2014. Farmland abandonment: threat or opportunity for biodiversity conservation? A global review. In Frontiers in Ecology and the Environment, vol. 12, pp. 288-296. http://dx.doi.org/10.1890/120348.
REBELE, F. - LEHMANN, C. 2002. Restoration of a landfill site in Berlin, Germany by spontaneous and directed succession. In Restoration Ecology, vol. 10, pp. 340-347. DOI: 10.1046/j.1526-100X.2002.01026.x.

STOATE, C. - BÁldi, A. - BEJA, P. - BOATMAN, N.D. - HERZON, I. - VAN DOORN, A. - DE SNOO, G.R. - RAKOSY, L. - RAMWELL, C. 2009. Ecological impacts of early 21 st century agricultural change in Europe - a review. In Journal of Environmental Management, vol. 91, pp. 22-46. DOI:10.1016/j.jenvman.2009.07.005.

SZYMURA, M. - SZYMURA, T.H. 2013. Soil preferences and morphological diversity of goldenrods (Solidago L.) from south-western Poland. In Acta Societatis Botanicorum Poloniae, vol. 82, pp. 107-115. DOI: 10.5586/asbp.2013.005.

ŠÁLY, R. - ŠURINA, B. 2002. Pôdy [Soils]. In Atlas krajiny Slovenskej republiky. Banská Bystrica : SAŽP, 342 pp. ISBN 80-88833-27-2.

VOSER-HUBER, M.L. 1992. Goldruten-Probleme in Naturschutzgebieten. Schriftenreihe Umwelt 167 [Problems with goldenrod in protected areas. Environmental series 167]. Bundesamt für Umwelt, Wald und Landschaft (BUWAL), Bern.

WAGENITZ, G. 1979. Solidago L. In HEGI, G. (Ed) Illustrierte Flora von Mitteleuropa. [Illustrated flora of Central Europe]. München : Carl Hanser Verlag, pp. 16-29.

WEBER, E. 2003. Invasive Plant Species of the World. A reference guide to environmental weeds. Wallingford, Oxon: CABI Publishing, 560 pp. ISBN 0-85199-6957.

WERNER, P.A. - BRADBURY, I.K. - GROSS, R.S. 1980. The Biology of Canadian Weeds, 45. Solidago canadensis L. In Canadian Journal of Plant Science, vol. 60, pp.1393-1409. DOI: 10.4141/cjps80-194.

WILSON, J.R.U. - DORMONTT, E.E. - PRENTIS, P.J. - LOWE, A.J. - RICHARDSON, D.M. 2009. Something in the way you move: dispersal pathways affect invasion success. In Trends in Ecology and Evolution, vol. 24 , pp. 136-144.

WITTENBERG, R. - COCK, M.J.W. 2001. Invasive alien species: A toolkit of best prevention and management practise. Wallingford, Oxon : CABI Publishing, xii 228 pp. ISBN 0851995691.

YUAN, G. 2008. Study on the control of Solidago canadensis by spraying metsulfuron-methyl. In Journal of Anhui Agricultural Sciences, vol. 32, pp. 14188-14189.

ZÁRUBOVÁ-PRAUSOVÁ, R. 2000. Invaze zavlečených rostlinných druhů v České republice. Část 1 [Invasion of introduced plant species in Czech Republic. Part 1] In Ochrana přirody, vol. 55, pp. 295-298.

ACT no. 543/2002 Coll. on Nature and Landscape Protection.

DECREE of Ministry of Environment no. 158/2014.

Received: October 19, 2015 